\title{
The Treatment of Industrial Effluents for the Discharge of Textile Dyes Using by Techniques and Adsorbents
}

Rahman F*

Department of Petroleum and Chemical Engineering, Faculty of Engineering, Institute Technology Brunei, Brunei

\begin{abstract}
Nowadays, the extraction of textile dyes from the wastewater in industry becomes an environmental worldwide issue. Water contamination is a big threat of not only for state of the environment but human body causes some chronic diseases. Textile dyes are worn to several types of products by fabrication, for paper, leather, plastic and some products, used in human daily life. Despite of containing various hazardous chemicals into textile dyes, it is necessary to be discharged from effluents of waste-water of industry through treatment as quick as possible. A number of technologies of different processes are effectively carried out for the treatment of industrial waste water by removal of colors. A variety of textile dyes is having different chemical structure with different properties dealing with the activity of industrial reaction. By reviewing of effects of textile dyes such as toxicity and mutagenicity, bacteria and organism embedded a prologue of the expulsion of metals to the environment. Certainly, for the dominion of textile dyes removal, adsorption can be regarded as effective method used by activated carbon, bentonite clay as adsorbent for the wastewater treatment in industry. Predominantly, it is a critical review of literature conferred the removal of textile dyes for the treatment of industrial wastewater by using techniques, technologies, adsorbents thoroughly. Certainly, Adsorption is the sole and ultimate approach for removal of textile dyes through the industrial wastewater treatment. This literature shows the feasibility of minimum cost adsorbent in term of maximum outcome of industrial wastewater treatment for textile dyes removal.
\end{abstract}

Keywords: Derivatives; Techniques; Processes; Adsorbents; Textile dyes

\section{Introduction}

The textile industrial wastewater is largely yielded by the textile industry all day long to night, might be called as a manufacturer through some operations related to the industrial production. However, all the textile industries consume a large quantity of water for several ways in order to different purposes. Although a good number of chemical of variable textile processing such as bleaching, scouring, dyeing, finishing and so forth, most obviously dyeing and finishing are the processes in which a variety of chemicals is widely used. Nonetheless, a large quantity of discharged wastewater turned to colored wastewater by the manufacturing of dyes in industry. But it now concerned of few causes like Toxicity, Accumulation and a few like them. If the toxicity increased and perfectly accumulated in nature, this process may be seemed like as a terrible view in environmental balance [1,2]. Textile dyes are ionized and organic, shows a strong affinity to the aqua solution and a bit on industry water, mostly used to be coloring during the manufacture of final product. Moreover, a lot of industries use finishing in the manufacturing process in leather, plastic, tanning and textile industry [3]. Furthermore, both of dye-manufacturing and textile finishing become a source of presumptive but only dye-manufacturing can discharge industrial waste-water without any disturbance.

Adsorption is a phantasm in which molecules of any state (gas or liquid) do focus at connecting surface with no reaction and the most effluent method for the removal of dyes from industrial waste water by treatment due to like ease of operation, little cost, efficiency and so on $[2,4]$. Activated carbon is a big potential for the treatment and used as an adsorbent. Other treatment methods can be operated during the process of wastewater of dyes removal not better than adsorption method with some factors such as cost, efficiency, operation system and so on. Besides, industrial wastewater for color removal can be treated biologically, chemically and physically [5]. As dyes are being produced in industry and later going for usage of the consumer product. Dyes have some common uses in business market-dyeing, soap, food, cosmetics, and textiles and so forth [6]. Color containing dyes is essential to be removed due to the amount of dyes (below $2.0 \mathrm{ppm}$ ). It also creates a big impact on the environment. To the removal of textile dyes from industrial waste water, followed by Wastewater effluent treatment. The process of waste-water treatment can be elected by some requirements, for instance cost, characteristics and others [7]. The treatment methods are also divided into primary, secondary and tertiary such sedimentation, removal of constituents and so on [8]. Today's, over the study of environment, the treatment of textile dyes of wastewater in industry is more essential and the effluents of color from industries which is known as textile industries demands to be deliberated as a contaminant. A number of substances are uncertain, for example aromatic compounds, synthetic dyes, heavy metals in dyes effluents. Many common dyes are insoluble and mostly used for the treatment in textile industry for the high stability. Later, cotton and fabrics are obviously applied with more difficult operations during the treatment of industrial colors wastewater. A large number of textile industries are located in subcontinents for example India, Pakistan, Bangladesh, Sri-Lanka and some other countries. Now, this sector still has a big influence of scattering the latest design of any fabric throughout the world within a short period of time and great potential of unutilized materials which are undiscovered and inherently related to the textile productions like yarns, cottons, fabrics, garments and so forth.

*Corresponding author: Fazlur Rahman, Department of Petroleum and Chemical Engineering, Faculty of Engineering, Institute Technology Brunei, Jalan Tungku Link, Gadong, Bandar Seri Begawan, Brunei, Tel: 6732461020; E-mail: rahman. fazrahman.fazlur48@gmail.com

Received February 04, 2016; Accepted February 19, 2016; Published February 26, 2016

Citation: Rahman F (2016) The Treatment of Industrial Effluents for the Discharge of Textile Dyes Using by Techniques and Adsorbents. J Textile Sci Eng 6: 242 doi:10.4172/2165-8064.1000242

Copyright: @ 2016 Rahman F. This is an open-access article distributed under the terms of the Creative Commons Attribution License, which permits unrestricted use, distribution, and reproduction in any medium, provided the original author and source are credited. 


\section{Denotation of textile dyes}

A content or material can be called as natural or synthetic used to altering the color during the unit operation or connecting the color into the fabrics. Textile dyes are derived from sources (i.e., coal tar) and defined as colored compounds containing several chemicals with different concentrations. To view of industrial purpose, dyes are not directly being used and utilized.

\section{Categorizing of textile dyes}

By consisting data collections, it narrates every dye, consisting properties of physical and chemical. Gathering of information of some dyes mentioned as much as possible for environmental factor. Afterwards, the dyes are selected and have effect to the nature and health factor by developing activities. These dyes are propagated to the textile industry of dying process [9] (Figure 1).

- Sulphur dyes are applicable in alkaline solution. They widely used for cotton, viscous and staple fibers and so forth.

- Disperse dyes are insoluble in water. They have worldwide usage in textile industry, basically for synthetics fibers like polyester and cellulose acetate such as Di-acetate, Tri-acetate and others. This dyes also used for nylon. They are applied on the dye bath at high temperature range around $120-140^{\circ} \mathrm{C}$.

- Direct dyes are the dyes, can be called as "substantive dyeing". Cotton used as natural fiber and viscous used as synthetic fiber. They also used for aqua solution. In solution, electrolysis and salts are available. Predominantly, direct dyes are used as the second dyes in worldwide. Direct dyes used for cotton, viscous.

- Azoic dyes are used for natural fibers, viscous, cellulosic fibers. They consist two soluble components to be formed colored molecules, are insoluble. The synthesis of azo dyes operated by two stages such as Diazotization $\left[\mathrm{HNO}_{2}\right]$ and Azo Coupling [

$$
\mathrm{Ar}^{\prime}[\mathrm{H}]
$$

Nylon can be classified into some forms such as (nylon 6:6), (nylon 6:10) and nylon (6:11) that commercially used in the world market. Some of dyes are not associated to fiber on dyeing processing. Dyes are collaborated into three categories such as

- Cellulose fiber

- $\quad$ Synthetic fiber

- $\quad$ Protein fiber

\section{Derivatives of textile dyes}

Toxicity: Dyes are mainly induced by toxicity. Dyes are synthesized to various metals occupying such as chromium $(\mathrm{Cr})$, Copper $(\mathrm{Cu})$, Zinc $(\mathrm{Zn})$, Cadmium (Cd) and more on are all violent. Dye molecules consist of two sort of molecule, might influence the toxicity of dye-colorant. The Toxicity could outcome by the elimination of metals to the nature or symbiotic action to raise the effect of toxics of metals. Study of toxicity is a vial of taking knowledge of toxic issues of materials, may be not well known and undecided. The easement of toxicity is performed by two tests, for example

- $\quad$ Sharp toxicity

- Enhancement toxicity

Firstly, Bacteria for example algae, protozoa are those who react to the sharp toxicity test. In the test, the organism is matured in the water-test where all the substances are present to necessary for growth.

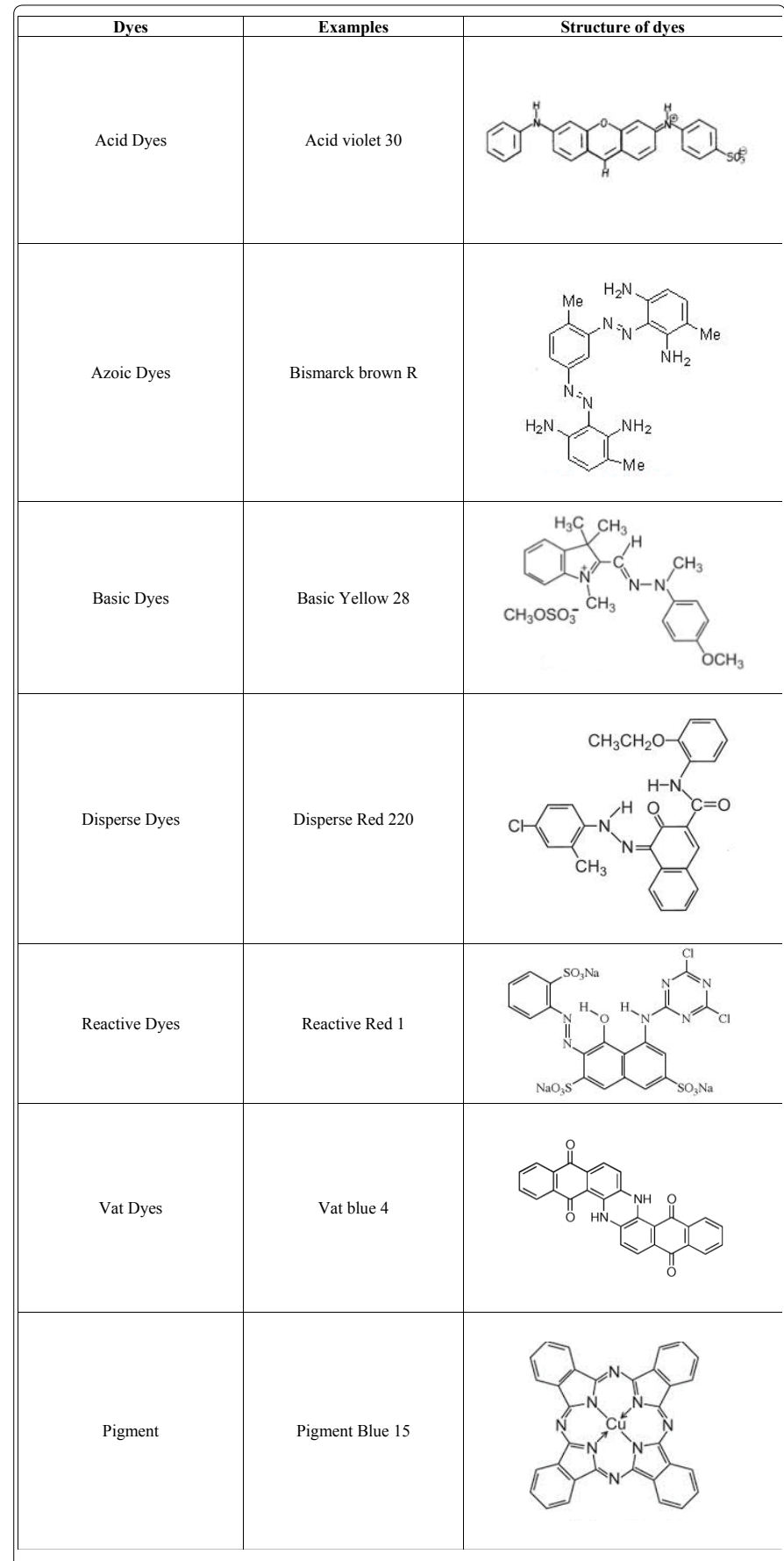

Figure 1: Some dyes and examples (structure) of dyes.

The number of organisms prompting in the sample, before and after growth, is estimated and the concentration of effluent required to affect with almost $50-60 \%$ of the organisms is found. Another test of the assessment of toxicity is enhancement toxicity. By using Enterobacter aerogenes, the enhancement toxicity test can be performed. Drinking water is contained the bacterium, developed with small growth as control. If any feasibility of increment growth is occurred to medium, the colonies are gained along with it. The reasons of toxicity may be determined through physical and chemical analysis by carrying out. The yield of dyes is also a big issue to the nature in terms of the event of toxicity [10]. By containing of disclosing of organisms are prototypical from the nature considering the time interval which are assertive to 
one or more components have many different concentrations, beneath the surroundings of environment are varied and grading the effects of poison. Thereby, tests which magnitude the concentration of a component, the appraisal of toxicity was executed. To be yielding a decisive effects, the time that is disclosure, is essential $[11,12]$.

Mutagenicity: The effluents of toxic hold chemicals (i.e., mutagenic, carcinogenic) to several organisms. The genetic materials may be affected and also damaged over different types of chemicals. Many dyes are originated from known as carcinogens (i.e., benzidine). They are familiar to be acquired and seemed as a potential threat. In issue of the sources of mutagenic activity is inspected all over the parts of the globe since many years. Furthermore, expressing of azoic and nitro compounds like nitro-aminoazobenzenes dyes are contained along with Disperse violet 93, Disperse orange 37, and Disperse blue 373. The water consumption by human presented conferred mutagenic activity related to nitro-aromatics and aromatic amines compounds [13].

In purpose of dyes removal, few of processes can be applicable for the industrial waste water treatment. Names are mentioned below [14-19]:

- $\quad$ Expected treatment process

- $\quad$ Rehabilitation process

- Gushing removal process

In addition, expected treatment process are used by few technologies such as biodegradation, coagulation, flocculation for presenting onto treatment of wastewater whereas others process are also available for waste water treatment by process of rehabilitation or process of gushing removal. To be exploiting of rehabilitation process are also worn as wastewater treatment technologies like ion-exchange, oxidation, and separation by membrane and so on. Additionally, technologies of removal of gushing process are assigned on treating of industrial wastewater. For instance, selective oxidation process (advanced) is engaged to gushing removal process [20,21] (Table 1).

Biodegradation: Microbial-degradation, frugal decolorizing, bio-remission are included to the mode of biodegradation. They are fully devoted to the industrial effluents treatment due to several microorganisms, for instance that yeasts, bacteria, fungi, algae and so forth are capable to assemble and degrade different hazardous-wastes. In the operation of biodegradation, the activity of biomass of microbial is not only influential but microbial biomass is relevant to it. Lead $(\mathrm{Pb})$, Chromium (Cr), Copper (Cu), Zinc ( $\mathrm{Zn})$, Arsenic (As), Cadmium (Cd) and so on are called heavy metals containing high concentration can have the effect is injurious on the action of microbial and also the microbial expansion. By adopting Fe (Iron) salts or Al (aluminum) drains the technology named coagulation. The treatment of textile derivations passed down by chemical coagulation completely. A major problem of coagulation is silt production, become a concern for carrying the process out. Photo-catalysis may be known as a new method of the advanced oxidation process, worn to clarify dye compounds. Many pros

\begin{tabular}{|c|c|c|}
\hline Technology & Pros & Cons \\
\hline Biodegradation & $\begin{array}{l}\text { Stable, } \\
\text { profitable }\end{array}$ & $\begin{array}{l}\text { Silt production high } \\
\text { process is sluggish }\end{array}$ \\
\hline Coagulation & Financially sufficient & Vending problem \\
\hline Oxidation process & $\begin{array}{l}\text { Quick process } \\
\text { productive }\end{array}$ & Cost of energy is high \\
\hline lon-exchange & $\begin{array}{l}\text { Effective small quantity of sludge } \\
\text { produced }\end{array}$ & $\begin{array}{c}\text { Generate concentrated } \\
\text { Brine }\end{array}$ \\
\hline $\begin{array}{l}\text { Membrane } \\
\text { separation }\end{array}$ & Is high & Pressure is high \\
\hline
\end{tabular}

Table 1: Pros and Cons of treatment by different technologies. are found in photo-catalytic degradation, like no more rudiments for further disposal in next. Photo-catalytic degradation is also applicable to the different dyes in different experiments [22].

\section{Removal of textile dyes by techniques of treatment}

Numerous methods are obviously relevant to the dyes removal of industrial waste water treatment. Among of them, it is feasible to identify the proper techniques are the best, can be described as below [3]:

- Chemical technique

- Physical technique

- Biological technique

A few of technologies have been applied for removal of textile dyes including above techniques, however, a device named microbial deterioration of color, is productive for clearing contaminant away from the nature [23]. By adsorption in lieu of degradation, some micro-organisms such as algae and fungi wash color out in effluents of industry. In consequence, colors abide in the environment. But under the surroundings that are assured, bacteria diminish colors [24]. Consistently, bacteria can lessen transitional by products like amines are aromatics adjacent to the enzyme of oxygenase and enzyme of hydroxylase [25].

- Physical technique is consisted of several methods such as sedimentation (clarification), screening, Nano filtration, reverse osmosis, electro dialysis and so forth. During the process of clarification, physical is a phenomena are allowed to be operated, relating to settling of solid by gravity. Sedimentation is one of the most physical treatment methods, used to attain treatment. In addition, another treatment method is aeration, by summing air to provide oxygen $\left(\mathrm{O}_{2}\right)$ to the wastewater. This phenomena also consists equalization and skimming. Due to high efficiency, A filtration method is renowned as Reverse Osmosis (RO) as well as can be suppressed that has drawn with good interest and thinking. The method can have a dormant of expelling of particles (over $90 \%$ ) in solution and a prime might be applicable to the treatment of industrial wastewater. This method like reverse osmosis method moves on a membrane called semi-permeable membrane with very small pores (about 0.6 nanometer) and its function at a high rate of operation in this method. Since couple of years ago, some experiments had performed to do removal of dyes through treatment in industry in which can be required the rate of discharge up to the $93 \%$ after operation [26].

Kashefi and Bahrami [27] examined the removal of vat dyes (anthrasol brown IBR) using by the process of reverse osmosis. A survey is applied to the effects of the experiment operating with some key parameters such as temperature $(\mathrm{T})$, feed concentration, and $\mathrm{pH}$ and so on. The experiment accepted use of $30 \mathrm{mg} / \mathrm{L}$ dye solutions where the final results demonstrated that the most ideal condition for the process was $\mathrm{pH}(=4)$ and temperature $\left(\mathrm{T}=25^{\circ} \mathrm{C}\right)$. The removal of colors was accomplished by following with the procedures through the membrane. Feed concentration was calculated beneath to some optimal conditions which disclosed that feed concentration is the largest and had a small positive supplement to the rate of color removal. In solution of feed, the effect of dye concentration is a specific parameter. Within the context of low concentration solutions a solution with a greater concentration brings greater elimination. Finally, many portions of solution through membrane and serial application of membranes are important aspects in promotion of rate of discharge and improvement of permeate quality in reverse osmosis process. As recognized, rate of discharge is attained with almost $\mathbf{9 4 \%}$ after completing through the membranes this experiment [27]. 
- Chemical technique is contained some methods like ozonation, neutralization, chlorination, and so on. Chemical treatment reposes of chemical reactions to develop the quality of water. Perhaps, chlorination is the most common chemical method. A strong oxidizing chemical named chlorine $\left(\mathrm{Cl}_{2}\right)$ used to kill bacteria and also the dissipation of wastewater. Neutralization is one of the most common methods, used industrial wastewater treatment. Neutralization consists of the addition of acid or base to modify $\mathrm{pH}$ levels back to neutrality. Ozonation is also one of the regular methods as chemical technique for using wastewater treatment. It is very competent for the deterioration of colors that are reactive, reduction of chemical oxygen demand, discharge of poisonous contaminants from the industrial dye effluents [28-32]. The main disadvantage of ozonation is duration of time. The period of time is halving of its total life. As the wastewater is remained in treatment, it can be lowered. Even if the condition is acidic for the ozonation, $\mathrm{pH}$ is required to the co-operation of treating industrial effluents for dyes removal [33]. Ozone $\left(\mathrm{O}_{3}\right)$ is more available to the environment and also used to be collected some data in experimental issues. It can be applied in gaseous state thoroughly.

Nabila et al. investigated for the sewage water treatment through the method of electrocoagulation by iron $(\mathrm{Fe})$ anode. A good number of operational parameters of the treatment either expertise or not have consequences which were interrogated and progressed. By the current density, the initial $\mathrm{pH}$, the volume of sodium chloride $(\mathrm{NaCl})$ and initial concentration of color, the wastewater of excess using by iron $(\mathrm{Fe})$ anode was prevailed. The optimum operating conditions of $\mathrm{pH}$ value was $7.6,65 \mathrm{~mA} / \mathrm{cm}^{2}$ as current density, $30 \mathrm{~min}$ of electrolysis time, and amount of sodium chloride as supporting electrolyte was $1 \mathrm{~g} / \mathrm{L}$ and gap distance of electrode was only $3 \mathrm{~cm}$. The determination appears that the optimal current density would be constant at $65 \mathrm{~mA} / \mathrm{cm}^{2}$ that provides the highest removal of Suspended Solids (S.S), Chemical Oxygen Demand (COD), and Biochemical Oxygen Demand (BOD) where these values falls from $507 \mathrm{mg} / \mathrm{L}, 760 \mathrm{mgO} / \mathrm{L}$, and $446 \mathrm{mgO} / \mathrm{L}$ to $5 \mathrm{mg} / \mathrm{L}, 98 \mathrm{mgO}_{2} / \mathrm{L}$, and $77 \mathrm{mgO}_{2} / \mathrm{l}$ respectively. Furthermore, the amount of released iron climbed as the adapted current density rises, however the Suspended Solids (S.S), Chemical Oxygen Demand (COD), and Biochemical Oxygen Demand (BOD) were leveled off on more current density above $65 \mathrm{~mA} / \mathrm{cm}^{2}$, thereby $65 \mathrm{~mA} / \mathrm{cm}^{2}$ was preceded as the optimal adjusted current density for sewage electro coagulation. The electro-coagulation is the process which is a very favorable pretreatment step for UF and RO process for the conversion of sewage water to irrigation water where it is high condition or drinking water which is decontaminated [34].

Stergiopoulos et al. discusses the electrochemical degradation treatment method of indigo carmine dye, that involves electrocoagulation, electro oxidation and advanced electrochemical oxidation using through the process of electro Fenton. The electrocoagulation process is implemented by electrodes of iron $(\mathrm{Fe})$. The ambiguous electro oxidation process is by steady Titanium (Ti) or Platinum $(\mathrm{Pt})$ and graphite electrodes in sodium chloride $(\mathrm{NaCl})$ electrolyte solution, and the electro-Fenton process is done by electrodes of iron $(\mathrm{Fe})$ and combined the amounts of hydrogen peroxide $\left(\mathrm{H}_{2} \mathrm{O}_{2}\right)$. A variety of electrochemical processes are explained like electrocoagulation, electrochemical and electro oxidation where their efficiencies analyzed and assessed. The initial dye concentration of $100 \mathrm{mg} \mathrm{l}^{-1}$ was quick and separated within a few minutes of electroprocessing time effectively. The electro-Fenton treatment is the fastest, efferent and financial process operated at very low current densities nearly 0.33 and $0.66 \mathrm{~mA} \mathrm{~cm}^{-2}$ and exhausting only $4.75 \times 10-3$ and $5.23 \times 10-3 \mathrm{kWh} \mathrm{m}^{-3}$ of treated solution. The electrocoagulation treatment with iron $(\mathrm{Fe})$ electrodes and the electro oxidation process with Titanium $(\mathrm{Ti})$ or Platinum $(\mathrm{Pt})$ electrodes conducted at enforced current densities of $5 \mathrm{~mA} \mathrm{~cm}^{-2}$ consumed 0.511 and $0.825 \mathrm{kWh} \mathrm{m}^{-3}$ of treated solution. The proposed procedure is a safe, economical method for discharge of indigo carmine dye from aqueous solutions and textile dye effluents. By employing the current densities of 0.33 and $0.66 \mathrm{~mA}$ $\mathrm{cm}^{-2} 100 \%$ the degradation of the dye was achieved in only 2 and 1 minutes of the method of electro-processing where consumption of energy was $4.75 \times 10^{-3}$ and $5.23 \times 10^{-3} \mathrm{kWh} \mathrm{m}^{-3}$ of treated dye solution [35] (Table 2).

- Fenton's reagent several methods are expressed by the chemical technique such as ozonation, Electrochemical, photochemical, electrochemical etc. However, Fenton's reagent as heating agent is comprised of decomposition. A mixture of hydrogen peroxide $\left(\mathrm{H}_{2} \mathrm{O}_{2}\right)$ and ferrous ion $\left(\mathrm{Fe}^{2+}\right)$ is renowned as Fenton reagents. The technique of Fenton can be thermic with alternative [36]. It is so efficient of fading for many dyes. Afterwards, iron $(\mathrm{Fe})(\mathrm{ll})$ or iron $(\mathrm{Fe})(\mathrm{lll})$ oxalate ion, UV light and Hydrogen peroxide have received a focus of lightening for especially synthetic dyes [37-39]. But about of the silt generation is a major disadvantage of this technique through flocculation of molecules of dyes. Peroxide techniques are associated with UV and Fenton's reagent whereas the insertion of UV light is constrained. One more thing is the cost of Fenton's reagent, influenced to the improvement of this method. In this technique of photo-Fenton, through of some reactions like photo reduction of iron $(\mathrm{Fe})(\mathrm{ll})$ to the ion of iron $(\mathrm{Fe})$ (lll), activity of fenton, photolysis of hydrogen peroxide $\left(\mathrm{H}_{2} \mathrm{O}_{2}\right)$, $\mathrm{H}_{2} \mathrm{O}_{2}$ are exploited quickly as far as possible. Hence, it can yield more $\mathrm{OH}^{-}$radicals than method of photolysis or method of Fenton that is conventional $[40,41]$. By virtue of little depletion of hydrogen peroxide $\left(\mathrm{H}_{2} \mathrm{O}_{2}\right)$, small price of removal of sediment, low dispersion of energy, inferior maintenance but flexibility is huge [42]. In contemplation of receiving the pros of burning power of Fenton's reagent exclude the desperation of $\mathrm{Fe}$ salts from solution, the process of exertion of hydrogen peroxide $\left(\mathrm{H}_{2} \mathrm{O}_{2}\right)$ has been regarded. Additionally, in behalf of the reaction of Fenton, along with the chemisorption of Fe powder, it can produce as good for removal of textile dyes than $\mathrm{Fe}^{2+}$ (ferrous ions) or $\mathrm{H}_{2} \mathrm{O}_{2}$ (hydrogen peroxide) [43]. Over a wide range of $\mathrm{pH}$ (around 5-8) and sediment is not produced with comparing to the Fenton's reagent, the action of oxidation of $\mathrm{H}_{2} \mathrm{O}_{2}$ (hydrogen peroxide) gains merit of its ability of application.

- Biological technique is one of the most cost-effective treatment methods than others treatment methods. Biological treatment is awkward to the regular variation and toxoids whereas it has good affability in design and activity. It is overviewed to be proven that biological treatment is the way of eradication of color with tolerable. Some metals which are heavy are involved of the wastewater of textile industry. In addition, the effluents of textile industry enclose with complex form and also some metals that are ionic [44]. For the shake of capability to outgrowth with little

\begin{tabular}{|l|l|l|}
\hline Methods & Advantages & Disadvantages \\
\hline Ozonation & $\begin{array}{l}\text { Volume is unchanged, stayed } \\
\text { in vapor-state }\end{array}$ & $\begin{array}{l}\text { Life duration is short (20 } \\
\text { min) }\end{array}$ \\
\hline Photochemical & Production of silt is off & $\begin{array}{l}\text { Metals, acids, halides } \\
\text { Produced as by-product }\end{array}$ \\
\hline Electrochemical & $\begin{array}{l}\text { Disruption of non-haphazard } \\
\text { compounds }\end{array}$ & $\begin{array}{l}\text { Price of power supply is } \\
\text { high }\end{array}$ \\
\hline Electrocoagulation & $\begin{array}{l}\text { Decolonization can be } \\
\text { achieved }\end{array}$ & $\begin{array}{l}\text { No failure of forming, } \\
\text { metallic }(\mathrm{OH}) \text { clouds in } \\
\text { wastewater }\end{array}$ \\
\hline
\end{tabular}

Table 2: Advantages and disadvantages of some methods of chemical technique. 
sludge, efficacy of price, benefaction of environment, some biological processes like bioaccumulation, bio colorization, and bio sorption are more supportive [45-47]. Because of the treatment of color effluents in industry, bioaccumulation and biosorption occupy good (potential) instead of methods are conventional. Moreover, they are known as the main technology in biological technique [48]. Biological systems are driven in situation of sites are contaminated, also called environmental benign were so costly and no contamination which is secondary. As the treatment of industrial color effluents, they can be said as the principle merits of biological technologies. Recently, for the treatment of color effluents related to industry, some necessary steps along with research have been carried out thoroughly on the methods of biological $[49,50]$. Efficiency with low degradation for many dyes, even no degradation efficiency is (suffered) to the process of degradation which might be as a demerit as well as it is not easy morally in process that is continuous $[49,51,52]$. By the biological materials which are passive, biosorption can be characterized as the static insolence of toxicants. As long as the treatment of industrial color effluents is largely harmful and continuous, the accommodating organism service is not desirable, can be said as merit of bioaccumulation and biosorption process. The use of biomass are dead is (flexile) to the situations of environment and concentrations of contaminant which run over of the current concern [13].

Shertate and Thorat inspected biodecolorization and degradation of textile diazo dye reactive blue-171 by- marinobacter sp.nb-6. Decolorization and Degradation of Reactive Blue 171 was achieved using by the adjusted marinobacter sp. NB-6 (Accession No. HF568873) detached from soil. The decolorization of dye Reactive blue 171 on 24 hours was up to $95.00 \%$ in nutrient broth consisting $8.0 \% \mathrm{NaCl}$ and exhibited $93.11 \%$ decolorization in half strength nutrient broth having the concentration of sodium chloride $(\mathrm{NaCl})$ which is equal. The percent decolorization of the dye was also executed by cell-free extract and was detected that the isolate can decolorize the dye $90.00 \%$ on 24 hours. The percent decolorization of the dye was disposed at 590 nanometer. The percent chemical oxygen demand (COD) debasement of the color by the segregate was $86.00 \%$. The degradation products formed after degradation were analyzed by GC-MS analysis and it was found that degraded Reactive Blue 171 to the products having several molecular weights. Khalid et al. reported enhanced decolorization of azo dyes by Shewanella putrefaciens strain AS96 in presence of yeast extract as co-substrate under hypersaline condition. Rania et al. used Glucose, Sucrose, Starch and Sodium citrate as carbon sources among which Starch was best for decolorization of Crystal violet up to $96 \%$. Gondaliya and Parikh reported the highest percentage decolourization $97.04 \%$ of Reactive Orange 16 was obtained by Serratia marcescenswhen additional supplement of glucose $(1 \mathrm{~g} / \mathrm{l})$ was added in nutrient broth [53].

Physicochemical approach: A number of different physical modes are available such as membrane filtration process. Further; the systems of physicochemical were expensive but feeble as well as not appropriate to wastewater of colors having a wide capacity [44]. The most typical process is membrane filtration process with some features. One of them is removal of all dyes by this. Another is its instant process but short area of space is needed. On the view of cost and volume, the cost is high and large volume cannot be handled by ability. By product of agricultural and industrial areas is done by non-ordinary adsorbent. It comprised to some advantages and dis-advantages. Firstly, adsorbent is active but not costly. Secondly, it provides smooth operation. Thirdly, it's also accessible in worldwide. The disadvantages are those such as toxic wastes are shifted from liquid to solid adsorbent as much as possible.
Adsorbent: The most effectual system is well-known as the adsorption process as established; the adsorption process is directly related to the wastewater treatment for industry. A good number of adsorbents are widely used such as activated carbon, seed of avocado pear, teak tree bark powder, natural clay, bentonite clay and so on. Activate carbon is not expensive, though its production creates trouble. Several types of by product can be feasible into activated carbon through conversion process from the area of agriculture and industry. Kind of thing is shell fiber of coconut, ash of fly (i.e., pearl millet husk, wheat straw, coconut straw etc.), corn rope, included to waste of wood and agriculture tended to produce activated carbon. The prerequisite of advantages for the removal of dyes process are some such as pore volume, high stability of heat, smooth production, and high stability of hydro thermal, no activity of catalytic and so forth. Many technologies already are prospered by researchers with some parameters like cost, efficiency, life cycle etc. by making the materials decolorizing from effusion of industry.

\section{Removal of textile dyes by adopting adsorbents}

3Carbon nanotubes as adsorbent for removal of dye: Carbon nanotubes (CNTs) are nanostructure shape having carbon atoms with some properties such as mechanical, chemical, thermal etc. Magnetic multi-wall carbon nanotubes (MMWCNTs) used to removal of cationic dyes from aqua solution [52-60]. Also single wall carbon nanotubes (SWCNTs), multi wall-carbon nanotubes (MWCNTs) and specially modified magnetic multi-wall carbon tubes (MMMWCNTS) used for different treatments on removal of dyes from industrial wastewater. Our effort is to look of the apply of the effective method for the treatment of industrial wastewater by removing of dyes by using SWCNTs or MWCNTs or MMWCNTs.

Fernando et al. investigated Adsorption of a textile dye from aqueous solutions by carbon nanotubes. The adsorbents were mainly characterized by using $\mathrm{N}_{2}$ adsorption/desorption isotherms, Raman spectroscopy and flashing and transmission electron microscopy. The effects of $\mathrm{pH}$, agitation time and temperature on adsorption capacity were reviewed. In the acidic $\mathrm{pH}$ region, the adsorption of the dye was supportive using by both of adsorbents. The contact time to obtain equilibrium isotherms at temperatures like 298-323 $\mathrm{K}$ was fixed at 4 hours for both adsorbents. Because reactive blue 4 dyes, Liu isotherm model gave the best fit for the equilibrium data. The maximum sorption capacity for adsorption of the dye occurred at $323 \mathrm{~K}$. Multi-walled carbon nanotubes (MWCNTs) and single-walled carbon nanotubes (SWCNTs) were better adsorbents for eliminating Reactive Blue 4 (RB-4) textile dye from aqueous solutions. The RB-4 dye interacted along with the MWCNT and SWCNT adsorbents at the solid or liquid interface while hanging in water. The equilibrium isotherm of the RB-4 dye was collected, and Liu isotherm model gave the best fit. Therefore, the maximum adsorption capacities were 502.5 and 567.7 $\mathrm{mg} \mathrm{g}^{-1}$ for MWCNT and SWCNT. The enthalpy $\left(\Delta \mathrm{H}^{\circ}\right)$ of adsorption implied which adsorption was the process that was an endothermic and the consequence of enthalpy was consistent with an electrostatic interaction of an adsorbent with the dye [37].

Activated carbon as adsorbent for removal of dye: Activated carbon is widely used as a large potential than other bio-adsorbents like expensive to the treatment for industry waste-water through method of adsorption. The adsorption of basic dyes (i.e., methylene blue) can be achievable by using activated carbon as an adsorbent. Experiments can be applied like batch experiment, equilibrium of tan is obtained almost 86 min with a variety of temperature variation in whatever place of an adsorbent such as activated carbon is worn. Isotherm models, for 
instance Langmuir and Freundlich are outfitted by adsorbent using as activated carbon [61].

Khraisheh et al. examined the Elucidation of Controlling Steps of Reactive Dye Adsorption on Activated Carbon. In this job, over the inspection of kinetics of adsorption, the rate-limiting traces of reactive dye adsorption onto FS-400 activated carbon were exemplified. Primarily, by these studies admitted that only $20 \%$ of the capacity of adsorption was available and obtained during the first 6 hours of mixing. The profiles of kinetic displayed that the adsorption process was maintained by diffusion that is external during the first $30 \mathrm{~min}$ of the reaction, after which internal diffusion restrained the process. What is more, the coefficients of external and internal diffusion and the rate of desorption declined after the period of interruption. Only $20 \%$ of the available ultimate capacity was achieved during the first $6 \mathrm{~h}$ of mixing with a dye solution. Interruption test results showed that adsorption of reactive dyes onto FS-400 was guarded by internal diffusion, with only a little effect from external diffusion [48].

Bentonite clay as adsorbent for removal of dye: The improvisation and adaption of physiochemical of Bentonite clay are apt of the removal of reactive dyes along with applications. At the beneath of upgrading condition with changing temperatue, Bentonite clay which comprised of properties for adsorption and approaching (reactive red 223) were observed at bottom of batch system during a period of time. Langmuir, Freundlich and Dubinin- Radushkevich isotherm models are fairly lighted by following of them. The upgrading conditions like amount of adsorbent, concentration of dye, temperature and so on were asses at the mark of no charge [62-65].

Tahir et al. discussed Physiochemical Modification and Characterization of Bentonite Clay and Its Application for the Removal of Reactive Dye. Thus the effective methods were ratified for the discharge of dyes and colorants from the textile effluents. In the current research, the discharge of textile dye reactive red 223 (RR 223) was operated by modified bentonite clay (MBC). The modification of bentonite clay was finalized beyond the manner of acid treatment. Moreover, the properties of adsorption of modified bentonite clay (MBC) towards RR 223 were prospected using by the batch method, on some temperatures (303-318 \pm 2 ) K under the optimized conditions. The equilibrium data of adsorption were equipped in Langmuir, Freundlich and Dubinin-Radushkevich adsorption isotherm models and the values of the respective constants were evaluated by employing standard graphical method. Feasibility of adsorption process (RL) and sorption energy (Es) was also resolved. It completes the symbolic changes in the capacity of adsorption toward reactive dyes. Adsorption, desorption, zero point charge $\mathrm{pH}$ (pzc), thermodynamic and kinetics studies were continued to incline the validity of process. The experiments of adsorption were rush beneath the optimal conditions of amount of adsorbent, break time, basic concentration and various temperatures. The adsorption models like: Freundlich, D-R and Langmuir adsorption isotherm models were applied for the mathematical description of the adsorption equilibrium data. From the values of $r 2$ it was suggested that Langmuir model is the best fitted model. Some parameters named as Gibbs free energy, enthalpy and entropy changes view that the adsorption of RR 223 onto MBC was instinctive and endothermic process. The kinetic data showed that the adsorption of RR 223 onto MBC followed the pseudo second order kinetics. The feasibility of adsorption and desorption process was surveyed in the study that is going to be running on. It was evaluated that inexpensive, available and active materials can be applied as adsorbents for the discharge of dyes. Certainly, low-cost adsorbents offer a lot of encouraging benefits for commercial purposes with respect to exertion and derogation of waste. In addition, the alternation of adsorbent as well as the reformation of color was performed by desorption experiments. The sorption and desorption capacity of MBC was found to be $95.15 \%$ and $78 \%$ [63-68].

Isotherm model: The most common isotherm models are Langmuir and Freunlich which is used to the application of wastewater treatment of industry [69-74].

Langmuir adsorption isotherm: It expresses the production of adsorbate which is seemed as one layer on the adsorbent remaining the exterior surface. Additionally, more adsorptions does not access in further steps. So, the Langmuir model exemplifies the equilibrium division of metal ions occurred in between the phase of solid and liquid [37]. The Langmuir isotherm is accurate to the monolayer adsorption. The homogeneous energies of adsorption onto the surface are estimated with the model and the reincarnation of adsorbate in the surface plane is no more [69-75] (Table 3).

Freundlich adsorption isotherm: To depict the adsorption flavors for the different surface is worn by this isotherm model.

Dubinin-Radushkevich adsorption isotherm: DubininRadushkevich isotherm is generally applied for the interpretation of the appliance of adsorption along with a energy named Gaussian dealing onto a surface, which is dissimilar [64-70]. More often, large solute activities equips this model effectively (Tables 4 and 5).

\section{Conclusion}

Several sorts of chemicals are interconnected to the textile industry such as removal, production of compounds and also the generation of some valuable products. Additionally, the outflow of textile industry is released as dyes while evaluated. The literature arrays a number of treatment methods are indispensable as well as regarded to the treatment of industrial wastewater for discharge of colors, though

\begin{tabular}{|c|c|c|c|}
\hline Name of dyes & $\begin{array}{c}\text { Name of } \\
\text { adsorbents }\end{array}$ & $\begin{array}{l}\text { Dye adsorption } \\
\text { capacity }(\mathrm{mg} / \mathrm{g})\end{array}$ & Isotherm model \\
\hline Organic dyes & $\begin{array}{c}\text { Surfactant } \\
\text { modified coconut } \\
\text { coir pith }\end{array}$ & 76.3 & $\begin{array}{l}\text { Freundlich and } \\
\text { Langmuir }\end{array}$ \\
\hline Reactive blue 4 & $\begin{array}{l}\text { Multi-walled and } \\
\text { single-walled } \\
\text { carbon nanotubes }\end{array}$ & 502.5 and 567 & Liu \\
\hline Reactive red 23 & Activated carbon & 59.88 & Freundlich \\
\hline Orange G & $\begin{array}{l}\text { Activated carbon } \\
\text { of Thespesia } \\
\text { populnea pods }\end{array}$ & 9.13 & $\begin{array}{l}\text { Freundlich and } \\
\text { Langmuir }\end{array}$ \\
\hline $\begin{array}{c}\text { Reactive blue } \\
171\end{array}$ & Activated carbon & 71.94 & Freundlich \\
\hline Congo red & Bagasse fly ash & 11.89 & Freundlich \\
\hline
\end{tabular}

Table 3: Dye adsorption capacities of different dyes.

\begin{tabular}{|c|c|c|c|}
\hline Name of dyes & Name of adsorbents & Values of pH & $\begin{array}{c}\text { Contact time } \\
\text { (equilibrium) }\end{array}$ \\
\hline Direct red & Calcined bone & $2-12$ & $60 \mathrm{~min}$ \\
\hline Methylene blue & Montmorillonite clay & $3-11$ & $120 \mathrm{~min}$ \\
\hline $\begin{array}{c}\text { Organic dyes } \\
\text { Breen anionic } \\
\text { dye }\end{array}$ & $\begin{array}{c}\text { Surfactant modified } \\
\text { peanut husk }\end{array}$ & $4-10$ & $180 \mathrm{~min}$ \\
\hline Reactive red & Activated carbon & $4.5-6.0$ & $300 \mathrm{~min}$ \\
\hline Reactive blue & $\begin{array}{c}\text { Multi-walled carbon } \\
\text { nanotubes }\end{array}$ & $2-10$ & $360 \mathrm{~min}$ \\
\hline
\end{tabular}

Table 4: Different $\mathrm{pH}$ values and contact time of different dyes. 
Citation: Rahman F (2016) The Treatment of Industrial Effluents for the Discharge of Textile Dyes Using by Techniques and Adsorbents. J Textile Sci Eng 6: 242. doi:10.4172/2165-8064.1000242

Page 7 of 9

\begin{tabular}{|c|c|c|}
\hline $\begin{array}{l}\text { Isotherm model of } \\
\text { Adsorption }\end{array}$ & $\begin{array}{l}\text { Limitations of Isotherm } \\
\text { model }\end{array}$ & Elemental Qualities \\
\hline$q_{e}=\frac{q_{m, L} \cdot K_{L} \cdot C_{e}}{1+K_{L} \cdot C_{e}}$ & $\begin{array}{l}\mathrm{C}_{\mathrm{e}}=\text { equilibrium } \\
\text { concentration of adsorbate } \\
\text { (mg/L) } \\
\mathrm{q}_{\mathrm{e}}=\text { the amount of metal } \\
\text { adsorbed per gram of the } \\
\text { adsorbent at equilibrium } \\
(\mathrm{mg} / \mathrm{g}) \\
\mathrm{qM} \mathrm{l}=\text { maximum monolayer } \\
\text { coverage capacity (mg/g) } \\
\mathrm{K} \mathrm{I}=\text { Langmuir isotherm } \\
\text { constant }(\mathrm{L} / \mathrm{mg})\end{array}$ & $\begin{array}{l}\text { Adsorption is consisted to } \\
\text { many layers on surface } \\
\text { which is diversified with } \\
\text { handling of active ites of } \\
\text { differential energy }\end{array}$ \\
\hline $\mathrm{q}_{\mathrm{e}}=\mathrm{K}_{\mathrm{F}} \cdot \mathrm{C}_{\mathrm{e}}^{\mathrm{n}}$ & $\begin{array}{l}\mathrm{K}_{\mathrm{F}}=\text { Freundlich isotherm } \\
\text { constant }(\mathrm{mg} / \mathrm{g}) \\
\mathrm{n}=\text { adsorption intensity } \\
\mathrm{C}_{\mathrm{e}}=\text { equilibrium } \\
\text { concentration of adsorbate } \\
(\mathrm{mg} / \mathrm{L}) \\
\mathrm{Q}_{\mathrm{e}}=\text { the amount of metal } \\
\text { adsorbed per gram of the } \\
\text { adsorbent at equilibrium } \\
(\mathrm{mg} / \mathrm{g})\end{array}$ & $\begin{array}{l}\text { Adsorption is consisted of } \\
\text { one layer having identical } \\
\text { sites and no communication } \\
\text { between adsorbed species }\end{array}$ \\
\hline $\begin{array}{c}E=\left[\frac{1}{\sqrt{2 B_{D R}}}\right] \\
\varepsilon=R T \ln \left[1+\frac{1}{C_{e}}\right] \\
\ln q_{e}=\ln \left(q_{s}\right)-\left(K_{a d} \varepsilon^{2}\right)\end{array}$ & $\begin{array}{l}\mathrm{q}_{\mathrm{e}}=\text { the amount of metal } \\
\text { adsorbed per gram of the } \\
\text { adsorbent at equilibrium } \\
(\mathrm{mg} / \mathrm{g}) \\
\mathrm{q}_{5}=\text { theoretical isotherm } \\
\text { saturation capacity }(\mathrm{mg} / \mathrm{g}) \\
\mathrm{KAD}=\text { Dubinin- } \\
\text { Radushkevich isotherm } \\
\text { Constant }\left(\mathrm{mol}^{2} / \mathrm{kJ}^{2}\right) \\
\mathrm{BDR}=\text { isotherm constant } \\
\mathrm{R}, \mathrm{T}, \text { Ce represents gas } \\
\text { constant }(8.314 \mathrm{~J} / \mathrm{mol} . \mathrm{k}) \\
\mathrm{C}_{\mathrm{e}}=\text { equilibrium } \\
\text { concentration of adsorbate } \\
\text { (mg/L) }\end{array}$ & $\begin{array}{l}\text { A energy called 'Gaussian' } \\
\text { allocated on surface, are } \\
\text { composite, devoted to } \\
\text { make difference between } \\
\text { adsorption of physical and } \\
\text { chemical by value of mean } \\
\text { free energy }\end{array}$ \\
\hline
\end{tabular}

Table 5: Synopsis of elemental qualities and limitations of isotherm models.

of some technologies of processes (i.e., flocculation, ion-exchange, coagulation, biodegradation), techniques (i.e., physical, chemical, biological) and adsorbents (i.e., carbon nanotubes, activated carbon, bentonite clay) are explicitly connected. Almost all methods are not adequate to separate contaminants due to consisting of some constraints such as huge cost, absence of capability, formation of auxiliary contaminants, so forth. In physical technique of treatment, depends upon high energy and then forms many risky outgrowths. Also, in chemical technique of treatment, electrochemical is high cost of power supply. Furthermore, for the treatment process, biodegradation is slow and high sludge production. Although the treatment of biological technique is quiet cheaper than others, adsorption is the maximum cost-effective surrounded by all methods by admitting two major influential factors such as content of application and minor cost of employment. This method can be particularly carried through along with lot of adsorbents, but a few of them which are inferior in cost, obviously suitable economically and environmentally with their certain applications. Undoubtedly, it can be mentioned that none of any process or technique have more appliances like adsorption. Over view to all discussion, only adopting adsorbent for textile dyes removal might be the energetic mode for the treatment of textile dye effluents in industry in comparison to following techniques for the treatment. In near future, it can be devoted to the alternative color departments which are used in worldwide textile industries.

\section{Acknowledgment}

The correspondence author (MD Fazlur Rahman) is thankful to all those people who encouraged me to be approaching on making this literature on textile dyes removal through industrial wastewater treatment.

\section{References}

1. Mishra AK, Arockiadoss T, Ramaprabhu S (2010) Study of removal of azo dye by functionalized multi walled carbon nanotubes. Chemical Engineering Journal 162: 1026-1034.

2. Joshi M, Bansal R, Purwar R (2003) Colour removal from textile effluents. Indian Journal of Fibre \& Textile Research 29: 239-259.

3. Karthik V, Saravanan K, Bharathi P, Dharanya V, Meiaraj C (2014) An overview of treatments for the removal of textile dyes. Journal of Chemical and Pharmaceutical Sciences 7: 301-307.

4. Damar Y (2012) Treatment of Textile Industry Wastewater by Sequencing Batch Reactor (SBR), Modelling and Simulation of Bio kinetic Parameters. International Journal of Applied Science \& Technology 2: 302-318.

5. Elsagha A, Moradib O, Fakhrib A, Najafic F, Alizadehd R, et al. (2013) Evaluation of the potential cationic dye removal using adsorption by graphene and carbon nanotubes as adsorbents surfaces. Arabian Journal of Chemistry pp: 1-8.

6. Kamil AM, Abdalrazak FH, Halbus AF, Hussein FH (2014) Adsorption of Bismarck Brown R Dye onto Multiwall Carbon Nanotubes. Environmental Analytical Chemistry 1: 1-6.

7. Goosen MFA, Shayya WH (2000) Water Management, Purificaton, and Conservation in Arid Climates. CRC Press 2: 1-352.

8. Ramnath Lakshmanan (2013) Application of Magnetic nanoparticles and reactive filter materials for wastewater treatment. universitetsservice us-ab $\mathrm{pp}$ : 1-57.

9. Kyzas GZ, Fu J, Matis KA (2013) The Change from Past to Future for Adsorbent Materials in Treatment of Dyeing Wastewaters, Materials 6: 5131-5158.

10. Immich APS, De Souza AAU, De Souza SMAGU (2009) Removal of Remazo Blue RR dye from aqueous solutions with Neem leaves and evaluation of their acute toxicity with Daphnia magna. Journal of Hazardous Materials 164: 15801585.

11. Spraghe JB (1973) The ABC's of pollutant bioassay using fish. In: Biologica Methods for the Assessment of Water Quality, American society for Testing and Materials. Philadelphia pp: 6-30.

12. Rand GM (1980) Introduction to Environmental Toxicology. Elsevier.

13. Batool S, Akib S, Ahmad M, Balkhair KS, Ashraf MA (2014) Study of Modern Nano Enhanced Techniques for Removal of Dyes and Metals. Journal of Nanomaterials pp: 20.

14. Kumar A, Chaudhary P, Verma P (2011) A comparative study on the treatmen methods of textile dye effluents. Global journal of environmental research 5 : 46-52.

15. Tsaia WT, Chang CY, Lina MC, Chiena SF,Suna HF, et al. (2001) Adsorption of acid dyeon to activated carbon prepared from agricultural waste bagasse by $\mathrm{ZnCl} 2$ activation. chemisphere 45: 51-58.

16. Manahan SE (2005) Fundamental of Enviromental Chemistry.

17. Adebayo, Otunola (2010) Assessment and Biological Treatment of Effluent from Textile Industry. African journal of biotechnology 9: 8365-8368.

18. Allen SJ, Oumanova BK (2005) Decolirization of Water/Wastewater Using Adsorption. Journal of the Univeristy of chemical technology and metallurgy 3: 175-192.

19. Abdelwahab O, El nemr A, El sikaily A, Khaled A (2005) Use of rice husk for adsorption of direct dyes from aqueous solution. Egyptian journal of aquatic research 31: 110-0354.

20. Nigam P, Armour G, Banat IM, Singh D, Marchant R (2000) Physical removal of textile dyes from e, uents and solid-state fermentation of dye-adsorbed agricultural residues. Bioresource Technology 72: 219-226.

21. Spellman FR (2000) Handbook of Water and Wastewater Treatment Plant Operations.

22. Beyene HD (2014) The potential of dyes removal from textile wastewater by using different treatment technology, a Review. International Journal of Environmental Monitoring and Analysis 2: 347-353.

23. Royer B, Cardoso NF, Lima EC, Ruiz VSO, Macedo TR, et al. (2009) Organ functionalized kenyaite for dye removal from aqueous solution. Journal of Colloid and Interface Science 336: 398-405. 
Citation: Rahman F (2016) The Treatment of Industrial Effluents for the Discharge of Textile Dyes Using by Techniques and Adsorbents. J Textile Sci Eng 6: 242. doi:10.4172/2165-8064.1000242

Page 8 of 9

24. Baath E (1992) Thymidine incorporation into macromolecules of bacteria extracted from soil by homogenization-centrifugation. Soil Biology and Biochemistry 24: 1157-1165.

25. Bader JL, Gonzalez G, Goodell PC, Ali AS, Pillai SD (1999) Chromiumresistant bacterial populations from a site heavily contaminated with hexavalent chromium. Water, Air, and Soil Pollution 109: 263-276.

26. Akbari A (2007) Polymeric nanomembranes and nanofiltration process.

27. Morteza MI, Bahrami F (2014) Removal of vat dyes from colored wastewater by reverse osmosis process, Bulletin of the Georgian National Academy of Sciences.

28. Liakou S, Pavlou S, Lyberatos G (1997) Ozonation of dyes. Water Science and Technology 141: 279-286.

29. Karahan O, Dulkadiroglu H, Kabdasli I, Sozen S, Babuna FG (2002) Effect of ozonation on the biological treatability of a textile mill effluent. Environmental Technology 23: 1325-1336

30. Moraes SGD, Freire RS, Duran N (2000) Degradation and toxicity reduction of textile effluent by combined photocatalytic and ozonation processes. Chemosphere 40: 369-373.

31. Tehrani-Bagha AR, Mahmoodi NM, Menger FM (2010) Degradation of a persistent organic dye from colored textile waste water by ozonation. Desalination 260: 34-38.

32. Selcuk H (2005) Decolourization and detoxicification of textile waste water by ozonation and coagulation processes. Dyes and Pigments 65: 217-222.

33. Ahmet B, Ayfer Y, Doris L, Nese N, Antonius K (2003) Ozonation of high strength segregated effluents from a woolen textile dyeing and finishing plant Dyes and Pigments 58: 93-98.

34. Hussien NH, Shaarawy HH, Shalaby MS (2015) Sewage Water Treatment via Electro coagulation Using Iron Anode. Asian Research Publishing Network (ARPN) 10: 8290-8299.

35. Dermentzis D, Giannakoudakis K, Sotiropoulos S (2014) Electrochemical Decolorization and Removal of Indigo Carmine Textile Dye From Wastewater. Global NEST Journal 16: 499-506.

36. Suty H, Traversay CD, Cost M (2004) Applications of advanced oxidation processes: present and future. Water science Tech $49: 227$.

37. Machado FM, Bergmannl CP, Lima EC, Adebayo MA, Fagan SB (2013) Adsorption of a textile dye from aqueous solutions by carbon nanotubes. Materials Research.

38. Swaminathan K, Sandhya S, Sophia AS, Pachhade K, Subrahmanyam YV (2003) Decolorization and degradation of $\mathrm{H}$-acid and other dyes using ferroushydrogen peroxide system. Chemosphere 50: 619-25.

39. Bandara J, Morrison C, Kiwi J, Pulgarin C, Peringer P (1996) Degradation/ decoloration of concentrated solutions of Orange II. Kinetics and quantum yield for sunlight induced reactions via Fenton type reagents. Journal of Photochemistry and Photobiology A: Chemistry 99: 57-66.

40. Gogate PR, Pandit AB (2004) A review of imperative technologies for wastewater treatment II: hybrid methods. Advances in Environmental Research 8: 553-97.

41. Bertanza G, Collivignarelli C, Pedrazzani R (2001) The role of chemical oxidation in combined chemical-physical and biological processes: experiences of industrial wastewater treatment. Water sci Technol 44: 109-16.

42. Tang WZ, Chen RZ (1996) Decolorization kinetics and mechanisms of commercial dyes by $\mathrm{H}_{2} \mathrm{O}_{2}$ /iron powder system. Chemosphere 32: 947-58.

43. Baath $\mathrm{E}$ (1998) Growth rates of bacterial communities in soils at varying $\mathrm{pH}$ a comparison of the thymidine and leucine incorporation techniques. Microbial Ecology 36: 316-327.

44. Erdal S, Taskin M (2010) Uptake of textile dye reactive black-5 by Penicillium chrysogenum MT-6 isolated from cement-contaminated soil. African Journal of Microbiology Research $4: 618-625$

45. Wang $\mathrm{H}$, Zheng, Su JQ, Tian $\mathrm{Y}$, Xiong XJ, et al. (2009) Biological Decolorization of the reactive dyes Reactive Black 5 by a novel isolated bacterial strain Enterobacter sp. EC3. Journal of Hazardous Materials 171: 654-659.

46. Aksu Z (2005) Application of biosorption for the removal of organic pollutants: a review. Process Biochemistry 40: 997-1026
47. Malik PK (2004) Dye removal from wastewater using activated carbon developed from sawdust: adsorption equilibrium and kinetics. Journal of Hazardous Materials 113: 81-88.

48. Khraisheh MAM, Al-Degs YS, Allen SJ, Ahmad MN (2001) Examined the Elucidation of Controlling Steps of Reactive Dye Adsorption on Activated Carbon. Ind Eng Chem Res 4: 1651-1657.

49. Vijayaraghavan K, Yun YS (2008) Biosorption of C.I. Reactive Black 5 from aqueous solution using acid-treated biomass of brown seaweed Laminaria $\mathrm{sp}$. Dyes and Pigments 76: 726-732.

50. Prasad MNV, De Oliveira Freitas HM (2003) Metal hyper accumulation in plants-biodiversity prospecting for phytoremediation technology. Electronic Journal of Biotechnology.

51. Stolz A (2001) Basic and applied aspects in the microbial degradation of azo dyes. Applied Microbiology and Biotechnology 56: 69-80.

52. Pearce Cl, Lloyd JR, Guthrie JT (2003) The removal of color from textile wastewater using whole bacterial cells: a review. Dyes and Pigments 58: 179196.

53. Shertate RS, Thorat PR (2013) Biodecolorization and Degradation of Textile Diazo Dye Reactive Blue-171 By- Marinobacter Sp.Nb-6 - A Bioremmedial Aspect. International Journal of Universal Pharmacy and Bio Sciences 3: 330-342.

54. Gupta VK, Kumar R, Nayak A, Saleh TA, Barakat MA (2013) Adsorptive removal of dyes from aqueous solution onto carbon nanotubes: A review. Advances in Colloid and Interface Science 193: 24-34.

55. Asad S, Amoozegar MA, Pourbabaee AA, Sarbolouki MN, et al. ( 2007) Decolorization of textile azo dyes by newly isolated halophilic and halotoleran bacteria. Bioresource Technology 98: 2082-2088.

56. Pandey A, Singh $P$, lyengar $L$ (2007) Bacterial decolorization and degradation of azo dyes. International Bio deterioration and Biodegradation 59: 73-84.

57. Moawad H, El-Rahim WMA, Khalafallah M (2003) Evaluation of biotoxicity of textile dyes using two bioassays. J Basic Microbiol 43: 218-229.

58. Gao HJ, Zhao SY, Cheng XY, Wang XD, Zheng LQ (2013) Removal of anionic azo dyes from aqueous solution using magnetic polymer multi-wall carbon nanotube nanocomposite as adsorbent. Chemical Engineering Journal 223 84-90.

59. Geyikci F (2013) Adsorption of Acid Blue 161 (AB 161) Dye from Water by Multiwalled Carbon Nanotubes. Fullerenes Nanotubes and Carbon Nanostructures 21: $579-593$

60. Ghaedi M, Kokhdan SN (2012) Oxidized multiwalled carbon nanotubes for the removal of methyl red (MR): kinetics and equilibrium study. Desalination and Water Treatment 49: 317-325.

61. Qu S, Huang F, Yu S, Chen G, Kong J (2008) Magnetic removal of dyes from aqueous solution using multi-walled carbon nanotubes filled with $\mathrm{Fe}_{2} \mathrm{O}$ particles. Journal of Hazardous Materials 160: 643-647.

62. Machado FM, Bergmann CP, Fernandes THM, Lima EC, Royer B, et al. (2011) Adsorption of Reactive Red M-2BE dye from water solutions by multi-walled carbon nanotubes and activated carbon. Journal of Hazardous Materials 192 1122-1131.

63. Tahir H, Sultan M, Qadir Z (2013) Physiochemical modification and characterization of bentonite clay and its application for the removal of reactive dyes. International Journal of Chemistry 5: 19-32.

64. Ver meulan TH, Vermeulan KR, Hall LC (1966) Fundamental. Ind Eng Chem 5: 212-223.

65. Arulkumar M, Sathishkumar P, Palvannan T (2011) Optimization of Orange $\mathrm{G}$ dye adsorption by activated carbon of Thespesia populnea pods using response surface methodology. J Hazard Materials 186: 827-834

66. Almeida CAP, Debacher NA, Downs AJ, Cottet L, Mello CAD (2009) Removal of methylene blue from colored effluents by adsorption on montmorillonite clay. J Colloidal Interface Sci 332: 46-53.

67. Arami M, Limaee NY, Mahmoodi NM, Tabrizi NS (2005) Removal of dyes from colored textile wastewater by orange peel adsorbent: equilibrium and kinetic studies. J Colloid Interface Sci 288: 371-376.

68. Zhao B, Xiao W, Shang Y, Zhu H, Han R (2014) Adsorption of light green anionic dye using cationic surfactant-modified peanut husk in batch mode. Arabian Journal of Chemistry. 
Citation: Rahman F (2016) The Treatment of Industrial Effluents for the Discharge of Textile Dyes Using by Techniques and Adsorbents. J Textile Sci Eng 6: 242. doi:10.4172/2165-8064.1000242

Page 9 of 9

69. Dada AO, Olalekan AP, Olatunya AM, Dada O (2012) Langmuir, Freundlich, Temkin and Dubinin Radushkevich Isotherms Studies of Equilibrium Sorption of $\mathrm{Zn}^{2+}$ Unto Phosphoric Acid Modified Rice Husk. Journal of Applied Chemistry 3: $38-45$

70. Ghaedi M, Khajehsharifi H, Yadkuri AH, Roosta M, Asghari A (2012) Oxidized multiwalled carbon nanotubes as efficient adsorbent for bromothymol blue. Toxicological and Environmental Chemistry 94: 873-883.

71. Kuo CY, Wu CH, Wu JY (2008) Adsorption of direct dyes from aqueous solutions by carbon nanotubes: Determination of equilibrium kinetics and thermodynamics parameters. Journal of Colloid and Interface Science 327: 308-315
72. Mall ID, Srivastava VC, Agarwal NK, Mishra IM (2005) Removal of congo red from aqueous solution by bagasse fly ash and activated carbon: Kinetic study and equilibrium isotherm analyses. Chemosphere 61: 492-501.

73. Pandey A, Singh P, lyengar $L$ (2007) Bacterial decolorization and degradation of azo dyes. International Biodeterioration and Biodegradation 59: 73-84.

74. Shah V, Verma P, Stopka P, Gabriel J, Baldrian et al. (2003) Decolorization of dyes with copper (II)/organic acid/hydrogen peroxide systems. Applied Catalysis B: Environmental 46: 287-292.

75. Kanawade SM, Gaikwad RW (2011) Removal of Methylene Blue from Effluen by Using Activated Carbon and Water Hyacinth as Adsorbent. International Journal of Chemical Engineering and Applications 2: 317-399. 